This item was submitted to Loughborough's Research Repository by the author.

Items in Figshare are protected by copyright, with all rights reserved, unless otherwise indicated.

\title{
Making and 'faking' a diasporic heritage
}

PLEASE CITE THE PUBLISHED VERSION

https://www.routledge.com/9781138631137

\section{PUBLISHER}

Routledge (c) selection and editorial matter, Robin Cohen and Carolin Fischer; individual chapters, the contributors

\section{VERSION}

AM (Accepted Manuscript)

\section{PUBLISHER STATEMENT}

This is an Accepted Manuscript of a book chapter published by Routledge in Routledge Handbook of Diaspora Studies on 2018-08-08, available online: https://www.routledge.com/9781138631137

\section{LICENCE}

CC BY-NC-ND 4.0

\section{REPOSITORY RECORD}

Scully, Marc. 2018. "Making and 'faking' a Diasporic Heritage”. figshare. https://hdl.handle.net/2134/26002. 


\section{Making and 'Faking' a Diasporic Heritage}

\section{Introduction}

Diasporic heritage is not automatically conferred. To claim diasporic heritage is to disrupt associations between birthplace, nationality and citizenship (Gilroy, 1997), and to proclaim political, cultural or affective allegiance to a real or imagined 'homeland' other than the place of current residence. However, such claims are subject to challenge and contestation. Individual claims to diasporic heritage must be rhetorically arranged around some form of 'proof' or justification that stands in for the more 'natural' association between nation and identity. While diasporic identification is fundamentally heterogenous, some common patterns can be drawn as to how such claims are made and defended, and equally how they are positioned as 'fake'. It is the contention of this Chapter therefore that 'authenticity' is central to understanding diaspora - not in terms of whether a transnational population may be considered an 'authentic' diaspora or not, but rather how individual and collective claims to diasporic status are authenticated. This focus on 'authenticity' can address the creative tension in the diaspora literature identified by Brubaker (2005) between boundary maintenance, and boundary erosion, or by Werbner (2002) as between ethnicparochialism and cosmopolitanism. Following Werbner, I will illustrate how this tension is not just the stuff of theory, but is a live concern for those in the diaspora.

My focus in this Chapter is primarily on the individual 'diasporan' and how she negotiates an 'authentic' diasporic heritage in relation to real or imagined diasporic communities, and the set of meanings around 'nation' and 'belonging' prevalent in both her 'homeland' and place of current residence. This is particularly pronounced for diasporans who were not themselves members of the migrant generation: my interpretation of 'diasporic heritage' highlights those of the second, third or subsequent generations. Although not exclusively so, such individuals' connection with a diasporic identity needs to be made and remade, not being underpinned by a personal narrative of migration. This focus on the individual and their relationship with wider social meanings of 'belonging' and 'authenticity' is specifically a social psychological one. It allows a consideration of how the supposed emancipatory potential of diaspora to enable hybridisation, liminality and deconstruction of hegemonic norms of nation measure up against the realities of diasporic lives as they are lived (Mitchell, 1997). Do individuals have agency to articulate 'authentic' diasporic identities as they wish, or are they subject to material and discursive constraints?

In order to investigate such issues, this Chapter is divided into two parts, roughly by the length of time that has elapsed since the original migration event. The first part addresses diasporans who are members of relatively identifiable diasporic communities: they may continue to have family or other ties with the country of origin and may be classified as ethnic minorities or as members of a migrant community in the country of residence. For such diasporans, the dilemma of authenticity occurs in expressing a personally relevant diasporic identity, in the context of constraints imposed by the 'homeland', the country of residence and other 'diasporans'. A diasporic heritage is here made and remade through culture, defined broadly. The second part addresses diasporans for whom the link with the original homeland has been lost, either through individual or collective trauma, or through 
the passage of time. For such individuals, 'authenticity' becomes a matter of proving a specific diasporic heritage through descent: this section will consider what forms of evidence are considered adequate to create an 'authentic' link.

\section{Section 1: Heritage and hegemony}

The fundamental heterogeneity of diaspora has been highlighted by numerous scholars (e.g. Anthias, 1998) who have cautioned against eliding intersectional differences of age, gender, sexuality, class, politics etc in discussing diasporic identity. I propose an additional difference that is occasionally overlooked - that between those with diasporic orientations and those with transnational orientations (cf. Scully, 2012). This requires a working distinction between transnationalism and diaspora, as they apply to the identifications of individuals. As Brettell (2006) has outlined there is a lack of consensus as to the relationship between the two concepts, with some arguing that transnationalism is supplanting diaspora, some that transnational individuals form the 'building blocks' of diaspora, and some that transnationalism represents a dual allegiance to host and origin countries, while diaspora represents a broader spread of allegiances. Adopting the latter distinction, it is possible to interrogate the notion of 'dual allegiances' further. Rather than arguing for the superior conceptual utility of either 'diaspora' or 'transnationalism', I argue that the two coexist as a series of perspectives, identifications and allegiances within which individual lives can be situated. From this perspective, 'transnationalism' represents the extent to which a life is lived in two or more countries simultaneously, whether that be materially, socially, economically or affectively. 'Diaspora' meanwhile represents the extent to which a 'national' life is lived outside the nation without necessarily reproducing the set of meaning-makings around identity that are hegemonic within the nation.

This has implications for making a diasporic heritage in the following ways. It is not unusual for a diasporic identity to evolve, over successive generations into something very different from identity in the origin country. For instance, the hegemonic set of meanings around Irish-American identity is quite different to the hegemonic set of meanings around Irish identity in Ireland. At times, this can lead to a contestation of 'authenticity': due to the assumption that the set of meanings around identity in the nation are, ipso facto, correct, this can lead to the positioning of diasporic identities as inauthentic. Contestation of the authenticity of such identities may happen virtually, due to increased communication capacity, but may also occur through encounters between diasporic individuals and more recent migrants, who may have more transnational orientations. It can be hypothesised that those who lead transnational lives will orient to the set of meanings around national identity currently hegemonic in the homeland, and are likely to position diasporic forms of identity as 'fake'.

A concrete example of such contestations can be found in the context of 1980s London, where recent Irish migrants encountered both older migrants from the previous 1950s wave of mass Irish emigration, and the children of this cohort, many of whom strongly identified as Irish. The more recent migrants, many of whom were from a relatively middle-class background, distanced themselves from the forms of diasporic Irishness they encountered in London, labelling them as inauthentic due to being culturally different from 'what we did at home' (Gray, 2004). It has been argued (e.g. Campbell, 1999, Mac an Ghaill \& Haywood, 2003) that these relatively middle-class migrants, in distancing themselves from what they perceived as 'old-fashioned' forms of Irishness, 
embodied transnational understandings of 'modern Ireland'. In particular those of Irish descent who claimed Irishness were positioned as inauthentic by recent migrants: leading to the epithet 'Plastic Paddy' to denote those who were seen as making illegitimate claims on Irishness (Hickman et al., 2005).

Simultaneously, those of Irish descent in English cities began to articulate hybridised city-based identities based on both their diasporic heritage and the specificity of their lived experience, such as London-Irish, Birmingham-Irish, Manchester-Irish etc. Such labels can be seen as a rhetorical response to being labelled 'fake' by ceding the ground of unhyphenated Irishness, but they can also be read as a more proactive claim on a more personally authentic identity. In my own research on discourses of Irishness in England (Scully 2012), I found that more recent migrants would regularly comment on the lack of knowledge of those of Irish descent about current affairs in Ireland as a means of positioning them as not 'properly' Irish. Meanwhile, those of Irish descent spoke of the need for their specific experiences and identifications to be recognised as valid, while admitting that their claims on Irishness were context-dependent. Long-term migrants on the other hand, based their claims of Irish 'authenticity' on continued involvement in an Irish diasporic community, arguing such communities had preserved 'real' Irish culture, that had been lost in Ireland itself due to modernisation. From such accounts, I argue (Scully, 2010) that there are three main discourses that can be drawn upon in articulating an ethno-national identity outside the nation:

1. Authenticity through collective experience and memory

2. Authenticity through transnational knowledge and practices

3. Authenticity through diasporic claim

These discourses are not exclusively associated with any one cohort in the diaspora, but are available (subject to constraints) to any individual seeking to proclaim the authenticity of their identity relative to the diaspora. Those not of the original migrant generation can assert the validity of their identities by appealing to the collective experience of their diasporic community, potentially through a kind of 'post-memory' (Hirsch, 2008). They may also draw on the discourse of transnational knowledge, perhaps by emphasising regular visits to the 'homeland'. However, it may become necessary to draw on the discourse of authenticity through diasporic claim, especially as a counter-argument to the assumption that 'authentic' identity resides in the 'homeland'. I have defined this discourse as "rhetorical attempts to counter or and deconstruct essentialist discourses of identity as dependant on birthplace and/or accent and instead suggest other means of demonstrating authenticity".

These forms of contestation of authenticity can also be seen in other diasporic groups. For instance, Yeh (2007) has highlighted different takes on authenticity throughout the Tibetan diaspora. She explores how the different routes taken by those of Tibetan heritage to the United States have resulted in cultural and linguistic intra-diaspora differences. The hegemonic understanding of 'authentic' Tibetan culture in the US is dominated by Tibetans who were exiled following the 1959 rebellion and their descendants: this cohort viewing themselves as exemplifying an 'authentic' Tibetan culture in exile, due to the subsequent promotion of Chinese language and culture in Tibet itself. However this understanding is challenged by more recent migrants from Tibet who draw on their geographical and experiential knowledge of the contemporary homeland to position their own Tibetan identities as the more authentic. A third group, who have experienced a hybridised Tibetan- 
Indian culture in Dharamsala, the home of the Dalai Lama, construct that city as the locus of 'authentic' Tibetan culture. While the political context is different, there are obvious parallels with the case of the Irish diaspora. Yeh uses the concept of 'habitus' to describe how her respondents negotiate the authenticity of their own identities. I would argue that one can also trace how they draw on the three discourses outlined above.

Along similar lines Mavroudi (2010) looks at contestation of authenticity in the Palestinian diaspora in Greece, along class lines as well as whether individuals have ever lived in Palestine. Mavroudi notes that the burden of proving oneself 'really' Palestinian appears to fall on those born in diaspora, who have not lived in Palestine. Such individuals must make diasporic claims for their authentic Palestinian identity, lacking the transnational knowledge of contemporary Palestine, or the collective experience of those who have lived through refugee camps.

How then, can diasporic claims to authentic identity be made in the context of the discursive constraints placed not only by essentialist associations between nation and identity, but also by competing discourses of authenticity in the diaspora? One tactic is to embrace the postmodernity of diaspora, and to seek to call into question the possibility of an 'authentic' identity. However, in the practice of diasporic lives as they are lived, this does not appear to be quite enough. Rather, individual diasporans seek to authenticate their identities through some form of personally meaningful evidence. This may come in the form of, inter alia, evidence of descent (more on which below), material objects (Turan, 2010) or some form of cultural practice, which may be individual or collective, for instance participation in parades or festivals, although the authenticity of such events is also subject to contestation (Klimt, 2000; Scully, 2012; Yeh, 2007).

One of the more personal modes of creating a personally authentic diasporic heritage that has been noted by researchers is through food. This can be through either the preparation and consumption of certain meals and foodstuffs linked with the homeland, or through seeking to import various brands of food from the homeland. For instance, Kneafsey and Cox (2002) have illustrated how the diasporic food practices of Irish women in Coventry included purchasing Irish brands of everyday foods, such as Galtee cheese, Tayto crisps, Barry's Tea and Kerrygold butter. Many of these brands, have subsequently drawn on their popularity in the diaspora as a promotional tool (McDaid, 2014). (Having said that, such brands can often provoke contestations of authenticity in themselves - which of the Northern or Southern variety of Tayto crisp is viewed as 'authentic' is an ongoing debate in the Irish diaspora.)

Mannur's (2007) analysis of culinary nostalgia in Asian diaspora literary studies highlights the role played by food and food preparation in diasporic communities, arguing that "a collective sense of nationhood, an affective longing for the home, and a fear of "losing" tradition morphs into a desire to retain viability and visibility through a systematic at- tempt to ossify the fragments and shards of cultural practices deemed "authentic"' (p.27). Mannur's analysis illustrates how such 'authenticity' only makes sense in a diasporic context - in the idealised homeland 'authentic' food is just food, and subject to regional variations. Moreover, she highlights that the level of attention to detail needed to ensure an 'authentic' dish can sometimes veer into the absurd - for a dish to be 'authentic', do all of the constituent ingredients need to be sourced from the homeland, or merely the recipe?

In drawing attention to the individual diasporan's need to 'navigate the unwritten codes of diaspora', Mannur highlights the various explicit and implicit constraints on making a personally authentic 
diasporic heritage. The resources available to make this diasporic heritage are also variable. In the second half of this Chapter, I turn now to those individuals and communities who are reliant on explicitly written codes in order to construct a diasporic heritage: those of genealogy, and more recently of DNA.

\section{Section 2: Descent and DNA}

In looking at the making of a diasporic heritage through the 'proof' offered by genealogy and genetics, the focus shifts from those of relatively recent migrant heritage, to those for whom the ancestral migration event is further in the past, and the link to the original homeland is now lost, or largely symbolic. Gans' (1979) concept of 'symbolic ethnicity' has been widely used in this context, although its assumption of assimilation clearly has limitations for those who are more obviously positioned as disadvantaged by their ethnicity. Nonetheless, while those who search for a diasporic heritage through genealogical/genetic means may not entirely identify with the hegemonic national identity of the country they live in, their nationality per se is generally not under question. Diasporic heritage is therefore not a given; it must be demonstrated either individually or collectively, through 'hard' evidence. It does not seem sufficient merely to assert a diasporic heritage: it must be in some way accounted for, in order to be 'authentic'

The use of genealogy to demonstrate an 'authentic' link with a diasporic past has been explored in detail in the American context by Catherine Nash, who has focussed on Irish-Americans, and Alondra Nelson, whose work is with African-Americans. Nash (2008) has demonstrated that for IrishAmericans involved in the pursuit of the genealogical origins, the focus is often to locate a specific geographical place where their ancestor(s) lived, that this "authenticates and verifies what was previously a general but unspecific ancestral connection". (This corresponds with my own findings on the importance of county identity in the Irish diaspora (Scully, 2013)). The attraction of the discovery of the ancestral home appears to be the air of legitimacy it leads to diasporic claims on Irishness - allowing Nash's respondents to distinguish themselves from 'temporary and superficial' performances of Irish ancestry in America, such as on St Patrick's Day. To be able to point to the specificity of one's ancestry is therefore a rhetorical device allowing one to assert a more authentic diasporic identity, than those who cannot do so: something Nash describes as a culture of 'competitive authenticity' in the diaspora.

Of course, as Nash points out, this is a form of essentialism in itself, and rather undermines theoretical claims for diaspora as a means of allowing for more hybrid liminal understandings of identity. Similarly, in many cases, focusing on a specific line of descent privileges one line of ancestry over others: it is often overlooked that many individuals will be members of several diasporas simultaneously, something that may be viewed as the ultimate occupation of 'diaspora space' (Brah, 1996). As states proactively engage with genealogical diasporas for tourism purposes, this raises the prospect of something of a market in persuading individuals that of all the possible diasporas they could potentially identity with, this one is the most authentic. However, such engagement must take into account the subtle ways in which diasporic heritage is made: the Irish Government's initiative to sell Certificates of Irish Heritage to those who could 'prove' Irish descent (effectively a certificate of authenticity) was widely seen as a failure, and discontinued after 4 years (Kenny, 2015).

In the African-American context, Nelson (2016) traces how the popularity of Alex Haley's Roots spurred a genealogy boom. She argues that Roots, and by extension, genealogy, provides a narrative 
of black life: that it "became an urtext of African diasporic reconciliation for a generation of Americans" (p.70). Perhaps the major attraction of this narrative of diasporic heritage, was that it could be made and fashioned on a personal and collective level, rather than imposed by slavery and its racist legacy. However, as Nelson illustrates, many individuals who wished to make a specific personalised connection to an African-born ancestor, found that they could not do so, due to a dearth of relevant records. As she explains, many of her respondents have subsequently turned to the promise offered by genetic genealogy to provide a link to a personalised African past.

This turn, which has been seen in many diasporic communities, as a means of lending a veneer of scientific legitimacy to the process of making a diasporic heritage, needs to be seen in the context of 'applied genetic history', which is marked by "'novel kinds of mediatisation, commercialisation and personalisation of historical knowledge as products" (Sommer, 2012, p. 226). The use of such 'products' as a means of affiliating oneself to a specific diaspora, has the potential to position shared DNA alongside shared language and culture in defining diaspora as an 'imagined genetic community'. It should, however, be pointed out that many population geneticists are wary about the commercial application of population genetics data, pointing out the problems and lack of nuance inherent in applying population data at an individual level, alongside the fact that such tests tend to focus on only one line of descent (see Jobling et al., 2016 for an overview of such concerns). Therefore, assumptions that DNA can fix a point of origin/'homeland' for individual diasporans looking for specificity should be viewed with caution.

Nelson's $(2008,2016)$ study of African-American users of genetic ancestry testing services illustrates how many were drawn to such services in the hope of a 'usable past', that would provide confirmation of pre-existing narratives, and a familial origin point in Africa. She traces how negotiating the complexity of genetic results can result in the forging of new, unanticipated links, and create "alternative social worlds with reimagined kinship arrangements and affiliations" (p.94). While such social worlds might appear to chime with the more liberatory potential of diaspora, it is also clear that marshalling DNA evidence to articulate diasporic links and identities is subject to contestation. Nelson draws attention to the potential of genetic information to act as a 'diasporic resource", allowing for the "weaving of a social mesh between African communities and their dispersed members, even in the absence of specific kinship ties" (2016, p.145). (One might remark that while such genetic links are scientifically questionable, they are culturally resonant.) She illustrates this through the example of the actor Isiah Washington, who following a DNA test that linked his maternal DNA ancestry with Sierra Leone, became increasingly involved with present-day Sierra Leone: establishing a charitable foundation, and ultimately adopting dual citizenship. The identification of a high-profile individual as a member of the 'DNA diaspora' undoubtedly counts as a 'diasporic resource' from the point of view of governments in the putative 'homeland': Nelson gives the example of the eagerness of government officials from Guinea-Bissau to claim Whoopi Goldberg, following a suggestion that she was genetically linked to the Papel and Bayote communities of that country.

(Lest it be thought that such claims are confined to African governments, decades of proactive uncovering of US Presidents' Irish ancestors arguably reached an apex with the establishment of the Barack Obama Plaza motorway service station near Moneygall, Co. Offaly). 
Such claims are tempered (or perhaps motivated) by the concerns of Africans in Africa, about the diasporic claims made by African-Americans on African diasporic heritage, arguing that African identity was best authenticated by a commitment to working in Africa, rather than through DNA, which Nelson illustrates through online comments. Returning to my typology of discourses of authenticity, this may be seen as an articulation of the need to demonstrate authenticity through transnational involvement, as opposed to the diasporic claim of assumed authenticity through DNA. However, what this example illustrates is the role of power dynamics in articulating an 'authentic' diasporic identity. While my previous work comes from the perspective that the discourse of authenticity through transnational knowledge is generally hegemonic, this is not the case in contestations of 'authentic' identity between Americans and West Africans. Nelson points to the asymmetrical nature of the exchange of this 'diasporic resource'.

DNA therefore represents something of a paradox in discussing diaspora, being both inescapably essentialist (being based on a biological essence), and something that can provoke a great deal of fluidity in the remaking of diasporic heritage. Nash (2015) builds on this paradox in cautioning that while viewing identity through the prism of genetic genealogy renders all of non-African humanity diasporic (in that we all ultimately trace our roots to migration from Africa), this is mediated through contemporary power relations which renders the diasporic origins of some individuals (and groups) 'normal' and others problematic.

Does DNA then, position us all in 'diaspora space', in perhaps a rather different way to Brah's (1996) original conceptualisation of the term? Thus far, this discussion of diaspora through descent has focussed on two 'prototypical' diasporas in Cohen's (2008) terms: the African, and the Irish. The concept of the Viking diaspora on the other hand, is relatively new to diaspora studies, although increasingly employed by medievalists (Jesch, 2015). Recent research by myself and colleagues on the Impact of Diasporas on the Making of Britain programme has explored among other things, how individuals might come to interpret a potential Viking heritage through DNA (Scully et al., 2013, 2016). The concept of being of Viking descent is a popular one in the North of England, particularly centred on York, whose urban identity trades to a major extent on its Viking heritage. As tracing a specific Viking ancestor is next to impossible genealogically, many of the participants in this research saw DNA as a way of authenticating their narratives of Viking descent. Whether this can be classed as making a 'diasporic' heritage depends on how far we are willing to stretch the concept of 'diaspora'. Certainly, responses from our participants that 'proof' of Viking heritage would make them feel more deeply rooted in Yorkshire are not particularly disruptive of hegemonic discourses of nation, identity and belonging. Nonetheless, Scandinavia was positioned in these responses as a point of origin, if not necessarily a 'homeland', and as somewhere respondents felt an affinity with. The 'imagined genetic communities' formed through DNA may therefore be classed as a new form of 'affinity diaspora' (Ancien, Boyle \& Kitchin, 2009): a potential resource for states that wish to attract interest and some form of loyalty from overseas, but that are unlikely to challenge hegemonic meanings of national identity.

\section{Conclusion}

I began this Chapter by questioning the levels of agency experienced by individual diasporans in making a diasporic heritage given the constraints imposed by hegemonic understandings of national (and transnational) identity. From the evidence I have presented, paradoxically, it appears to be 
those 'diasporans' with the most tangential claims on the present-day 'homeland', who have the most scope in fashioning a diasporic identity. Claiming a 'Viking' diasporic identity through DNA falls within the category of recreational genomics: as a 'placeholder identity', it does not pose a challenge to the sets of meanings around being 'Norwegian' and 'Danish' in those modern-day countries. However, where diasporans have a greater stake in having their claims on identity recognised as 'authentic', contestation of this authenticity appears to be more fraught, whether within the diaspora, between diasporic and transnational individuals/communities, or between the diaspora and the 'homeland'. The dilemma of 'authenticity' is thus most pronounced for those that occupy the liminal space of diaspora: if only for acknowledgement that that liminal space may be a personally authentic place to be.

\section{References}

Ancien, D., Boyle, M. and Kitchin, R., 2009. Exploring diaspora strategies: Lessons for Ireland. Maynooth: National Institute for Regional and Spatial Analysis, NUI Maynooth.

Anthias, F., 1998. Evaluating 'Diaspora': beyond ethnicity?. Sociology, 32(3), pp.557-580.

Brah, A., 1996. Cartographies of diaspora: contesting identities London: Routledge.

Brettell, C.B., 2006. Introduction: global spaces/local places: transnationalism, diaspora, and the meaning of home. Identities: Global Studies in Culture and Power, 13(3), pp.327-334.

Brubaker, R., 2005. The 'diaspora'diaspora. Ethnic and racial studies, 28(1), pp.1-19

Buettner, E., 2008. "Going for an Indian": South Asian restaurants and the limits of multiculturalism in Britain. The Journal of Modern History, 80(4), pp.865-901.

Campbell, S., 1999. Beyond 'plastic paddy': A re-examination of the second-generation Irish in England. Immigrants \& minorities, 18(2-3), pp.266-288.

Cohen, R., 2008. Global diasporas: An introduction. Abingdon: Routledge.

Gans, H.J., 1979. Symbolic ethnicity: The future of ethnic groups and cultures in America. Ethnic and racial studies, 2(1), pp.1-20.

Gilroy, P. 1997. Diaspora and the Detours of Identity. In K. Woodward (Ed.) Identity and Difference., pp.301-343 London: Sage.

Gray, B., 2004. Women and the Irish diaspora. London: Routledge.

Hickman, M.J., Morgan, S., Walter, B. and Bradley, J., 2005. The limitations of whiteness and the boundaries of Englishness: second-generation Irish identifications and positionings in multiethnic Britain. Ethnicities, 5(2), pp.160-182.

Hirsch, M., 2008. The generation of postmemory. Poetics today, 29(1), pp.103-128.

Jesch, J., 2015. The Viking Diaspora. London: Routledge.

Jobling, M.A., Rasteiro, R. and Wetton, J.H., 2016. In the blood: the myth and reality of genetic markers of identity. Ethnic and Racial Studies, 39(2), pp.142-161. 
Kenny, C. 2015 'Certificate of Irish Heritage Abandoned After Low Uptake', Irish Times, 17 August. Available http://www.irishtimes.com/life-and-style/abroad/generation-emigration/certificate-of-irishheritage-abandoned-after-low-uptake-1.2320015

Klimt, A., 2000. Enacting national selves: Authenticity, adventure, and disaffection in the Portuguese diaspora. Identities Global Studies in Culture and Power, 6(4), pp.513-550.

Kneafsey, M. and Cox, R., 2002. Food, gender and Irishness-how Irish women in Coventry make home. Irish Geography, 35(1), pp.6-15

Mac an Ghaill, M. and Haywood, C., 2003. Young (Male) Irelanders Postcolonial EthnicitiesExpanding the Nation and Irishness. European Journal of Cultural Studies, 6(3), pp.386-403.

Mannur, A., 2007. Culinary nostalgia: Authenticity, nationalism, and diaspora. Melus, 32(4), pp.11-31.

Mavroudi, E., 2010. Contesting identities, differences, and a unified Palestinian community. Environment and Planning D: Society and Space, 28(2), pp.239-253.

McAuliffe, C., 2008. Transnationalism within: Internal diversity in the Iranian diaspora. Australian Geographer, 39(1), pp.63-80.

McDaid, A., 2014. 'Sure we export all our best stuff': Changing Representations of Emigration in Irish Television Advertising. Nordic Irish Studies, pp.41-56.

Mitchell, K., 1997. Different diasporas and the hype of hybridity. Environment and Planning D: Society and space, 15(5), pp.533-553.

Nash, C., 2008. Of Irish descent: Origin stories, genealogy, \& the Politics of Belonging. Syracuse, NY: Syracuse University Press.

Nash, C., 2015. Genetic geographies: the trouble with ancestry. Minneapolis: University of Minnesota Press.

Nelson, A., 2008. Bio science: Genetic genealogy testing and the pursuit of African ancestry. Social Studies of Science, 38(5), pp.759-783.

Nelson, A., 2016. The social life of DNA: Race, reparations, and reconciliation after the genome. Boston: Beacon Press.

Scully, M., 2010. Discourses of authenticity and national identity among the Irish diaspora in England (Doctoral dissertation, The Open University).

Scully, M., 2012. Whose day is it anyway? St. Patrick's day as a contested performance of national and diasporic Irishness. Studies in Ethnicity and Nationalism, 12(1), pp.118-135.

Scully, M., 2012. The tyranny of transnational discourse:'authenticity'and Irish diasporic identity in Ireland and England. Nations and nationalism, 18(2), pp.191-209.

Scully, M., 2013. BIFFOs, jackeens and Dagenham Yanks: county identity,"authenticity" and the Irish diaspora. Irish Studies Review, 21(2), pp.143-163.

Scully, M., King, T. and Brown, S.D., 2013. Remediating Viking origins: genetic code as archival memory of the remote past. Sociology, 47(5), pp.921-938.

Scully, M., Brown, S.D. and King, T., 2016. Becoming a Viking: DNA testing, genetic ancestry and placeholder identity. Ethnic and Racial Studies, 39(2), pp.162-180. 
Sommer, Marianne. 2012. 'It's a Living History, Told by the Real Survivors of the Times - DNA.' Anthropological Genetics in the Tradition of Biology as Applied History." In Genetics and the Unsettled Past: the Collision of DNA, Race and History, edited by Keith Wailoo, Alondra Nelson and Catherine Lee, 225-246. London: Rutgers University Press.

Turan, Z., 2010. Material objects as facilitating environments: the Palestinian Diaspora. Home cultures, 7(1), pp.43-56.

Werbner, P., 2002. The place which is diaspora: citizenship, religion and gender in the making of chaordic transnationalism. Journal of ethnic and migration studies, 28(1), pp.119-133.

Yeh, E.T., 2007. Exile meets homeland: politics, performance, and authenticity in the Tibetan diaspora. Environment and Planning D: Society and space, 25(4), pp.648-667. 